\title{
Investigate the Toxoplasma gondii infection in the consumed beef in Al-Diwaniyah province
}

\author{
F.M. Sakban ${ }^{1}$ and N.N. A'aiz ${ }^{2}$ \\ Department of Veterinary Microbiology, College of Veterinary Medicine, University of Al-Qadisiyah, Al-Qadisiyah, Iraq. \\ Email: ${ }^{1}$ noaman.aaiz@qu.edu.iq, ${ }^{2}$ farah.bird@yahoo.com
}

(Received January 11, 2019; Accepted March 24, 2019)

\begin{abstract}
Toxoplasmosis is very important zoonotic disease in the world cause by an obligate intracellular protozoan parasite called Toxoplasma gondii can infect human and all warm-blood animals, beef consider from most important source for infection with T. gondii and there is no really data and study about the rate of the infection in beef in Al-Diwaniyah province, so for this reason the aim of this work was designed. A total of 300 samples which collected from heart, tongue, muscles, of 100 slaughtered beef of local and imported cattle, throughout the period from September 2017 to May 2018, initially examined microscopically for searching on $T$. gondii bradyzoites then all suspected samples was subjected to conventional PCR technique through $B$ Igene amplification to confirm the infection, in addition to analyzed the recorded data for each sample to determine the effect of some factors on prevalence of infection like organ, season and animal age. Out of 300 tested samples only 53 were confirm positive T. gondii DNA. The infection in local beef was higher $(22 \%)$ than in imported (13.5\%), while there is no difference in infection among different examined organs. Regarding to effect of some factors, the autumn season recorded highest rate of infection with significant differences rather than others seasons in both local and imported beef, whereas, age appears with no effect on infection. The local cattle meat is riskier than the imported due to the higher rate of infection with $T$. gondii, and the animal age cannot affect on the infection rate, in comparing with the season which play role in this rate.
\end{abstract}

Keywords: Toxoplasma gondii, Beef, Iraq, Diwaniyah, PCR Available online at http://www.vetmedmosul.com, (C) 2020, College of Veterinary Medicine, University of Mosul. This is an open access article under the CC BY 4.0 license (http://creativecommons.org/licenses/by/4.0/).

\section{التحري عن الإصابة بمقوسة كوندي في لحوم الأبقار المحلية والمستوردة في محافظة الديوانية فرح محمد صكبان و نعمان ناجي عايز}

$$
\text { فرع الأحياء المجهرية البيطرية، كلية الطب البيطري، جامعة القادية، القادسية، العراق }
$$

داء المقوسات هو من اهم الأمر اض المشتركة حول العالم ويسببه طفيلي مقوسة كوندي، وهو الأنو من الأو الي مجبرة التطفل داخل الخلايا

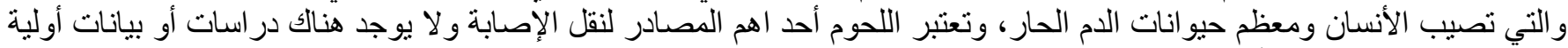

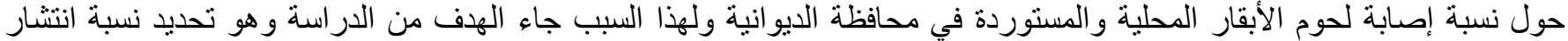

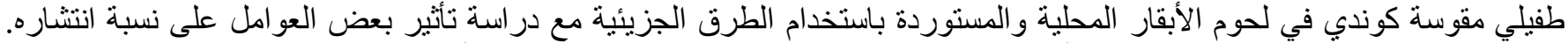

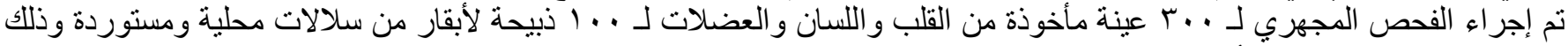

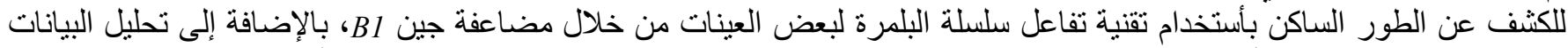

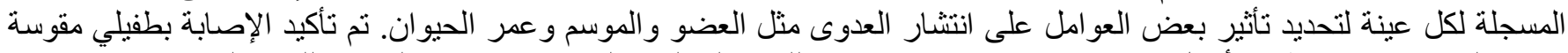

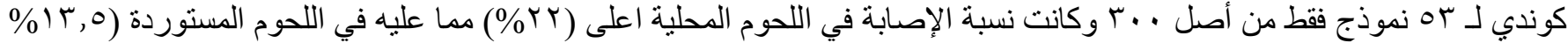




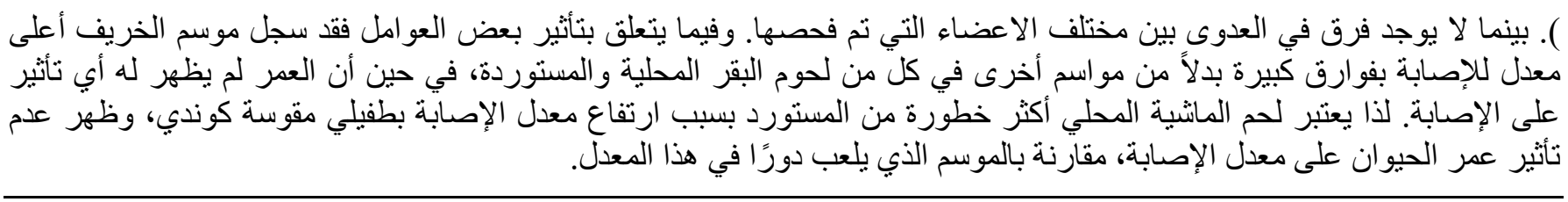

\section{Introduction}

Toxoplasma gondii is a protozoan obligate intracellular parasite and its cause Toxoplasmosis, zoonosis disease worldwide distribution can infect all warm-blood animals which act as intermediate host and felids like domestic cats known as definitive hosts (1). The importance of this disease occurring during pregnancy period especially in women, where this parasite cause many congenital defects in fetus in addition its severe life-threating infections, also immunocompromised individuals consider the target to this parasite, and can cause illness in many features, in both the weakness of immune system play important role in occurrence of the infection (2). The main ways of disease transmission are ingestion of oocyst that contain sporozoites by food, water, or any way lead to contact with cat feces, transmission via placenta, and consumption of raw or under cooked meat until dealing with it, so about $28 \%$ pregnant women get infection by this way (3). The role of beef in transmission of $T$. gondii infection to human is unclear yet because of the infection by it is reported as the one of the risk factors that cause acute infection, on the other hand the theory believed that cattle poor persistence of parasite and the tissue cyst are not very persistent in cattle, thus it is necessary make large scale screening of cattle for the present of $T$. gondii to clarify the role of cattle as a source of infection (4). According to the importance of toxoplasmosis as a zoonotic disease and its close relationship to the health of community, role of meat in transporting of $T$. gondii infection to human, and there are no previous studies in this field in Al- Diwaniyah province the aim of study was designed.

\section{Material and method}

Three hundred samples were used in this study which collected from heart, tongue, muscles, of 100 slaughter animals of local and imported cattle.

\section{Isolation of $T$. gondii bradyzoites}

Meat samples were subjected to a peptic digestion method for isolate suspected toxoplasma bradyzoites from the examined tissue to prepare it for DNA extraction, briefly $10 \mathrm{~g}$ of meat from each sample was cut by scissors for a very small pieces and they were transferred into a sterile test tube, $10 \mathrm{ml}$ from digestive solution (pepsin $2.6 \mathrm{~g}$, $\mathrm{NaCl} 5 \mathrm{~g}$, HCL $7 \mathrm{ml}$, Distilled water $485 \mathrm{ml}$ this amounts for $500 \mathrm{ml}$ from digestive solution) were added to the tube and incubated at $40^{\circ} \mathrm{C}$ for 30 minutes, then the digestate was poured through two layers of gauze into a flask and then the filtrate was centrifuged $(5000 \mathrm{rpm}$ for $10 \mathrm{~min})$, the supernatant was discarded and $5 \mathrm{ml}$ of sodium bicarbonate solution (NaHCO $3.6 \mathrm{~g}+500 \mathrm{ml}$ distilled water) was added to precipitate then mixed well and re-centrifuged (5000 rpm for $10 \mathrm{~min}$ ), after that supernatant was discarded again and the precipitate was examined microscopically. The positive sample's precipitates were suspended in $600 \mu \mathrm{l}$ normal saline and mixed well, then used for DNA extraction.

\section{Genomic DNA Extraction}

Genomic DNA were extracted from each prepared samples of meat by used the gSYAN DNA extraction Kit (Geneaid, USA), depending on the company's instructions.

\section{PCR Amplification}

Conventional PCR was performed for detection $T$. gondii based on amplify the $B 1$ gene, this procedure was applied according to technique explained by (5) this gene was target to produce the specific primer, as forward primer (5' AAAAATGTGGGAATGAAAGAG 3'), and revers primer (5' ACGAATCAACGGAACTGTAAT 3'), and the conditions of PCR thermo cycler (Amplification steps) included initial denaturation at $95{ }^{\circ} \mathrm{C}$ for 5 minute, 30 cycle for denaturation at $95^{\circ} \mathrm{C}$ for 30 second, annealing at $56^{\circ} \mathrm{C}$ for 30 second, extension at $72{ }^{\circ} \mathrm{C}$ for 30 second, 1 cycle for final extension at $72{ }^{\circ} \mathrm{C}$ for 5 minute, the PCR products of $B 1$ gene was analyzed by $1 \%$ agarose gel electrophoresis to detect an expect 469 bp product.

\section{Results}

The result of molecular examination showed that $22 \%$ $(33 / 150)$ and $13.5 \%(20 / 150)$ of local and imported cattle's meat respectively were infected with $T$. gondii protozoan (Figure 1).

Regarding to the distribution of infection among examined organs the results showed there were $31.5 \%$ $(15 / 48), 21 \%(10 / 47)$ and $15.9 \%(8 / 55)$ of the muscles, tongues, and hearts respectively from the local and $18 \%$ $(9 / 50), 12.9 \%(7 / 54)$ and $8.6 \%(4 / 46)$ for muscles, tongues and hearts respectively from imported meat were infected but with no significant difference, (Table 1). 


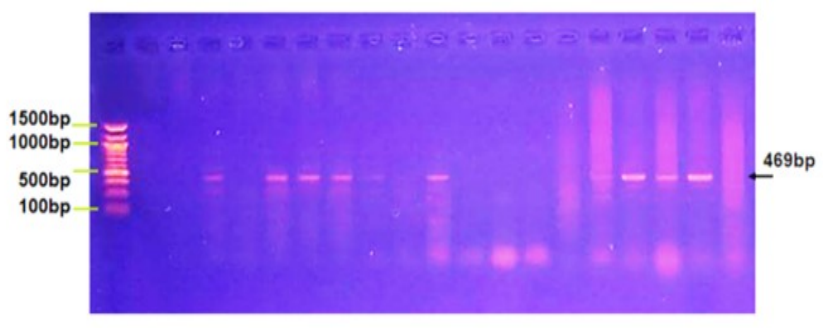

Figure 1: Molecular positive result of $T$. gondii infection according to $B 1$ gene (469 bp) analysis.
The rate of infection according to seasonal variation appeared highest in Autumn (September to November) in both local and imported meat and recorded 14.7\%, 5.4\% respectively when comparing with other studied seasons (Table 2). According to the effect of age on the rate of infection the result revealed that all studied ages can infect with $T$. gondii but there are no significant difference among them although the ages' categories of 1-3 years and more than 3 years appeared with highly infection in local and imported meat respectively in comparing with other (Table 3).

Table 1: Distribution of T. gondii infection in local and imported beef according to the organs

\begin{tabular}{lcccccc}
\hline \multirow{2}{*}{ Organs } & \multicolumn{3}{c}{ Local beef } & \multicolumn{3}{c}{ Imported beef } \\
\cline { 2 - 7 } & Examined No. & Positive No. & Percentage (\%) & Examined No. & Positive No. & Percentage (\%) \\
\hline Muscle & 48 & 15 & 31.5 & 50 & 9 & 18 \\
Tongue & 47 & 10 & 21 & 54 & 7 & 12.9 \\
Heart & 55 & 8 & 15.90 & 46 & 4 & 8.6 \\
Total & 150 & 33 & 22 & 150 & 20 & 13.5 \\
\hline$x^{2}$ & & 4.189 & & & 1.805 & \\
P value & & 0.123 & & & 0.406 & \\
\hline
\end{tabular}

Table 2: Infection of T. gondii in local and imported beef according to the seasons

\begin{tabular}{lcccccc}
\hline \multirow{2}{*}{ Months } & \multicolumn{3}{c}{ Local beef } & \multicolumn{3}{c}{ Imported beef } \\
\cline { 2 - 7 } & Examined No. & Positive No. & Percentage (\%) & Examined No. & Positive No. & Percentage (\%) \\
\hline Autumn (Sept - Nov) & 70 & 21 & 30 & 45 & 12 & 26.6 \\
Winter (Dec - Fab) & 40 & 4 & 10 & 66 & 0 & 0 \\
Spring (Mar - May) & 40 & 8 & 20 & 39 & 8 & 20.5 \\
\hline$x^{2}$ & \multicolumn{3}{c}{$6.061^{*}$} & & & $18.817^{*}$ \\
P value & 0.048 & & & 0 \\
\hline
\end{tabular}

$x^{2}$ : chi-square. ${ }^{*}$ significant difference at $\mathrm{P}<0.05$

Table 3: Infection of $T$. gondii in local and imported beef according to the age

\begin{tabular}{lcccccc}
\hline \multirow{2}{*}{ Age } & \multicolumn{3}{c}{ Local beef } & \multicolumn{3}{c}{ Imported beef } \\
\cline { 2 - 7 } & Examined No. & Positive No. & Percentage (\%) & Examined No. & Positive No. & Percentage (\%) \\
\hline$>1$ year & 30 & 4 & 13 & 15 & 1 & 0.15 \\
$1-3$ year & 57 & 17 & 30 & 48 & 8 & 16.6 \\
$<3$ year & 64 & 12 & 19 & 87 & 11 & 12.6 \\
\hline$x^{2}$ & & 3.757 & & & 1.074 & \\
P value & & 0.153 & & & 0.584 & \\
\hline
\end{tabular}

\section{Discussion}

Meat is an important source of human food, and among different kinds of meat, beef represent one of the most common consumption types (6). T. gondii infects beef as whereas other meat and lead to many health problems like congenital defects and abortion in both humans and livestock (7). This is the first study that deals with the $T$. gondii infection in local and imported beef in in Al-
Diwaniyah / Iraq, in which molecular technique was used to detect the infection through amplification of Blgene, serological study associated with beef was done by Zakaria (8) in Iraq (Mosul) to detect the T. gondii infection in different meat juices by LAT test, while another many Iraqi studies were deals with the prevalence of infection in sheep, aborted women, chicken, stray cats (9-13) and there are many researches on pregnant and aborted women in Iraq. 
Out of 300 beef samples 33 (22\%) and 22 (13.3\%) for local and imported beef respectively were achieved a positive result. These results were compatible to the results of Ehsan in Iraq (Mosul) who mentioned in serological study that $17 \%$ of examined sample revealed $T$. gondii infection also in molecular study was done by Amdouni et al (14) from Tunisia showed that among 150 cattle meat samples that $19.3 \%(29 / 150)$ gave positive result. So, the agreement between the results of the previous studies and the current study revealed the risky in consumption of infected beef with $T$. gondii.

The results of the present work were less than that values found in Northern Portugal $50 \%$ by Lopes et al (15), and the study in Colombia included 180 samples from chicken, swine, and beef, targeted $B 1$ gene which recorded $37 \%$ by Franco-Hernandez et al (16). In another side the prevalence of $T$. gondii in present study was higher than those recorded in Brazil and Switzerland (2\% and 3.8\%, respectively) $(17,18)$, also the study that where done in Iran by (19) which recorded $4 \%$ rate of infection.

In comparing study by Navari et al (20) between local and imported meat in Iran, showed that the imported meat recorded higher infection rate $26 \%$ than local meat $6 \%$, this results are conflict with present study which found the infection in local animals more than infection in imported, thus at the end all these differences among different studies may depend upon many factors like climate conditions, numbers of tested samples, rearing methods, false negative, and different sample size.

Concerning to the infection of $T$. gondii in different examined organs no significant difference was recorded in the current study. This recording is in agreement with other previous study made by Burrells et al (21) on calves when studied the probable variations of different organs infection and showed that there is no clear predilection site within bovine tissues.

According to the effect of seasons on infection with $T$. gondii, Autumn was recorded the highest rate of infection with significant difference, the present study consistent with the study (22) in China where they revealed that $T$. gondii was found in $6(3.33 \%)$ samples collected in Autumn and $1(0.56 \%)$ collected in winter, this indicated that seasons might have important impacts on the presence of $T$. gondii, likewise (23) recorded rising in infection rate during winter and spring than Autumn and summer and referred to that seasonal variation of $T$. gondii infection in human are remarkably different than animals, also seasonal variation study on pregnant women in France appeared that the maximal risk of infection between end of summer to end of Autumn (24). this may be related to the availability of favorable conditions for oocysts maturation and sporulation to become infective (25).

Regarding to the animal's age the current study mention that the highest prevalence of infection was recorded in age
1- 3 years $30 \%$ (16.6) for local and imported respectively, while lowest prevalence rate observed in ages less than 1 year $1.2 \%$. This results near to many another like the study did by Navari et al (20) and he referred to that infection in cattle and sheep in Iran were increase during ageing in rate $3.7 \%$ for animals less than 2 years while the rate of infection was $9.09 \%$ in animals with ages range from 2-4 years, another molecular study was done by Amdouni et al (14), referred to that younger animals less infection than the older animals, serological study in Sudan conducted by Elfahal et al (26) for detection of $T$. gondii in cattle, mentioned that the prevalence of $T$. gondii infection was significantly higher $36.4 \%$ in animals less than one year old than those above two years $12.8 \%$. In fact many factors impact on $T$. gondii infection incidence such as the type of livestock management and production, the hygiene standards of abattoirs, food processing, the density of cats in the environment, and the habits of human consumers, also the geographical location with respect to altitude, and the prevailing climatic conditions and the important factor is present of the final host (27).

\section{Conclusion}

The infection of consumed meat with $T$. gondii can't be negligible due to the valuable rate of infection severity of the problem on community healthy, in addition to that the local cattle meat are more risky than the imported due to the higher rate of infection with $T$. gondii, the parasite can infect all examined organs (heart, muscles, tongue) in the same rates approximately, and the infection rate can be effected by season but not by age of animals.

\section{Acknowledgment}

I extend my thanks and appreciation to all Veterinarians who cooperated with me for getting samples in Al-Diwaniyah abattoirs.

\section{Reference}

1. Dubey JP. Sources of Toxoplasma gondii infection in pregnancy. BMJ. 2000;321(7254):127-128. Doi:10.1136/bmj.321.7254.127.

2. Halonen SK, Weiss LM. Toxoplasmosis. Handb Clin Neurol. 2013;114:125-45. Doi: 10.1136/bmj.321.7254.127.

3. Kravetz JD, Federman DG. Toxoplasmosis in pregnancy. Am J Med. 2005;118(3):212-6. Doi: 10.1016/j.amjmed.2004.08.023.

4. Jones JL, Dargelas V, Roberts J, Press C, Remington JS, Montoya JG. Risk factors for Toxoplasma gondii infection in the United States. Clin Infect Dis. 2009;49(6):878-84. Doi: 10.1086/605433.

5. Ortega A, Acosta Viana KY, Guzman E, Segura JC, Alvarez M, Jimenez M. Prevalence and risk factors of Toxoplasma gondii in fattening pigs farm from Yucatan, Mexico. Biol Med Res Inter. 2013;231497. Doi: $10.1155 / 2013 / 231497$.

6. Dubey JP. A review of toxoplasmosis in cattle. Vet Parasitol. 1986;22:177-202. Doi:10.1016/0304-4017(86)90106-8. 
7. Saadatnia G, Golkar M. A review on human toxoplasmosis. Scand J Infect Dis. 2012;44:805-814. Doi: 10.3109/00365548.2012.693197.

8. Zakaria EG. Detection of Toxoplasma gondii antibodies in different meat juices. Raf J Sci. 2011;22(4):17-25. https://www.iasj.net/iasj?func $=$ article\&aId $=6804$.

9. Alkhaled MJA, Yakoob AY, Al-hamadani AHU. An investigation of Toxoplasmosis in Free Range chickens, Industrial chickens and duck in mid Euphrates area of Iraq. Al-Qadisiya $\mathrm{J}$ Vet Med Sci.2012;11(2):17-24. qmeds.iraqjournals.com/article 80791.htm

10. Switzer AD, McMillan-Cole AC, Kasten RW, Stuckey MJ, Kass PH, Chomel BB. Bartonella and Toxoplasma infections in stray cats from Iraq. Am J Trop Med Hyg. 2013;89(6):1219-1224. Doi: 10.4269 ajtmh.13-0353.

11. Mohammed AA, Abdullah SH. Diagnostic study of toxoplasmosis in domestic chickens in Sulaimani province. Al-Qadisiya J Vet Med Sci. 2013;12(2):63-69. https://www.iasj.net/iasj?func=article\&aId=80649.

12. Mohammed NS, Al-A'ssie AH, Al-saqur IM. Genotyping of Toxoplasma gondii Isolated from aborted Iraqi Women. Diyala J Med. 2015;9(1):44-52. https://www.iasj.net/iasj?func=article\&aId=139622.

13. A'aiz NN. Determination of Toxoplasma gondii lineages of sheep in Wasit, Iraq. Iraqi J Vet Sci. 2016;30;2:23-26. Doi: 10.33899/ijvs.2016.121379.

14. Amdouni Y, Rjeibi MR, Rouatbi M, Amairia S, Awadi S, Gharbi M. Molecular detection of Toxoplasma gondii infection in slaughtered ruminants (sheep, goats and cattle) in northwest Tunisia. Meat Sci. 2017;133:180-184. Doi: 10.1016/j.meatsci.2017.07.004.

15. Lopes AP, Vilares A, Neto F, Rodrigues A, Martins T, Ferreira I, Gargaté MJ, Rodrigues M, Cardoso L. Genotyping characterization of toxoplasma gondii in cattle, sheep, goats and swine from the north of Portugal. Iran J Parasitol. 2015;10:465-472. Doi: PMC4662747.

16. Franco EN, Acosta A, Cortes J, Gomez-Marin JE. Survey for Toxoplasma gondii by PCR detection in meat for human consumption in Colombia. Parasitol Res. 2015;115(2):691-695. Doi: $10.1007 / \mathrm{s} 00436-015-4790-7$

17. Santos SL, Costa KDS, Gondim LQ. Investigation of Neospora caninum, Hammondia sp. and Toxoplasma gondii in tissues from slaughtered beef cattle in Bahia, Brazil. Parasitol Res. 2010;106(2):457-461. Doi: 10.1007/s00436-009-1686-4.

18. Berger AE, Herrmann DC, Schares G, Müller N, Bernet D, Gottstein B, Frey CF. Prevalence and genotypes of Toxoplasma gondii in feline faeces (oocysts) and meat from sheep, cattle and pigs in Switzerland. Vet Parasitol. 201;177(3):290-297. Doi:10.1016/j.vetpar.2010.11.046

19. Rahdar M, Samarbaf A, Arab L. Evaluating the prevalence of Toxoplasma gondii in meat and meat products in Ahvaz by PCR Method. Jundishapur J Microbiol. 2012;5(4):570-573. Doi: $10.5812 / \mathrm{jjm} .4280$.

20. Navari D, Saadati D, Nabavi R, Al-ipour Eskandani M. Epidemiology and molecular prevalence of Toxoplasma gondii in cattle slaughtered in Zahedan and Zabol districts, south east of Iran. Iran J Parasitol. 2017;13(1):114-119. Doi: PMC6019591.

21. Burrells A, Taroda A, Opsteegh M, Schares G, Benavides J, Dam C, Bartley PM, Chianini F, Villena I, van der Giessen J, Innes EA, Katzer F. Detection and dissemination of Toxoplasma gondii in experimentally infected calves, a single test does not tell the whole story. Parasit Vectors. 2018;11(1):45. Doi: 10.1186/s13071-018-2632-

22. Liu X, He Y, Han D, Zhang Z, Li K, Wang S, Xu L, Yan R, Li X. Detection of Toxoplasma gondii in chicken and soil of chicken farms in Nanjing region. Infect Dis Poverty. 2017;6(1):62. doi: 10.1186/s40249-017-0277-3. Doi: 10.1186/s40249-017-0277-3.

23. Logar J, Soba B, Premru T, Novak Z. Seasonal variations in acute toxoplasmosis in pregnant women in Slovenia. Clin Microbiol Infect. 2005;11(10):852-855. Doi: 10.1111/j.1469-0691.2005.01244.x.

24. Morin L, Lobry JR, Peyron F, Wallon M. Seasonal variations in acute toxoplasmosis in pregnant women in the Rhone-Alpes region (France). Clin Microbiol Infect. 2012;18:E401-E403. Doi: /10.1111/j.1469-0691.2012.03898.X.

25. Yan C, Liang LJ, Zheng KY, Zhu XQ. Impact of environmental factors on the emergence, transmission and distribution of Toxoplasma gondii. Parasit Vectors. 2016;10(9):137. Doi: 10.1186/s13071-016-1432-6

26. Elfahal AM, Elhassan AM, Hussien MO, Enan KA, Musa AB, ElHussein AM. Seroprevalence of Toxoplasma gondii in dairy cattle with reproductive problems in Sudan. ISRN Vet Sci. 2013;19:895165. doi: 10.1155/2013/895165. Doi.org/10.1155/2013/895165.

27. Hall S, Ryan KA, Buxton D. The epidemiology of toxoplasma infection. In Toxoplasmosis: a comprehensive clinical guide Joynson DH, Wreghitt TJ editors. Cambridge: Cambridge University Press; 2001. 58-124 p. Doi: /10.1086/340624. 